\title{
DEVELOPMENT OF LUMINESCENT BACTERIA AS TRACERS FOR GEOLOGICAL RESERVOIR CHARACTERIZATION
}

\author{
Quarterly Report for the Period \\ January-March 1991
}

By

Jeannette $\mathrm{w}$. King

Work Performed Under Contract No. AC22-90BC14666

\author{
Edith C. Allison, Project Manager \\ Bartlesville Project Office \\ P. O. Box 1398 \\ Bartlesville, OK 74005
}

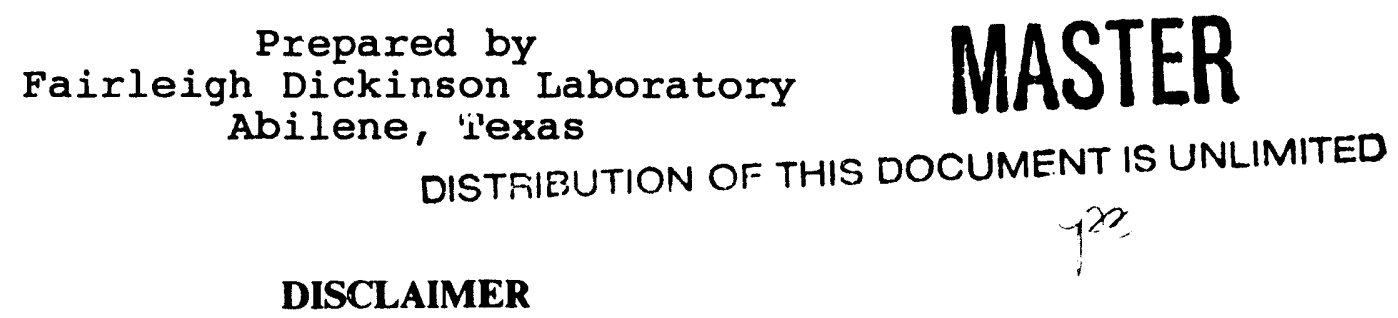

This report was prepared as an account of work sponsored by an agency of the United States Government. Neither the United States Government nor any agency thereof, nor any of their employees, makes any warranty, express or implied, or assumes any legal liability or responsibility for the accuracy, completeness, or usefulness of any information, apparatus, product, or process disclosed, or represents the its use would not infringe privately owned rights. Reference herein to any specific commercial product, process, or service by trade name, trademark, manufacturer, or otherwise does not necessarily constitute or imply its endorsement, recommendation, or favoring by the United States Government or any agency thereof. The views and opinions of authors expressed herein do not necessarily state or reflect those of the United States Government or any agency thereof. 


\title{
SUMMARY OF PROGRESS
}

\author{
OBJECTIVES
}

This research project resulted from recognizing the problem of being unable to accurately distinguish communication between wells in producing oil zones which may or may not be continuous. Such a determination is necessary when considering EOR whether it is water flooding, carbon dioxide, or other methods which increase the sweep efficiency. Various kinds of chemical tracers are available, but they are expensive and many might be considered hazardous for underground aquifers. Other biological tracers are available, but have never been developed for oil reservoir conditions.

Bioluminescent bacteria seemed an obvious candidate because they thrive in saline waters (usually $3 \%$ salt) which have been contaminated by oil spills.

\section{SUMMARY OF TECHNICAL PROGRESS}

The technical progress of this project is summarized in the following paragraphs.

We have completed the tasks by investigating and reporting the:

1. accumuiation of biolumnescent bacteria and information relating to growth and luminescent investigations,

2. adaption of bioluminescent bacteria to formation waters, and

3. transportation of bioluminescent bacteria through representative cores.

Some variations to the originally proposed task descriptions were made in the best interest of the goal objectives and are appropriately indicated.

\section{SIGNIFICANT ACCOMPLISHMENTS}

Bioluminescent bacteria grow well in the formation brine where no oxygen is present - in other words in typical oil field reservoirs. The presence of oxygen was determined to be necessary for luminescence, but not for growth. This phenomenon has been corroborated in the published literature. 
Contrary to our original predictions, cultures acquired from culture banks adapted more readily and completely to formation waters than did those collected from marine environments. One particular culture exhibited excellent growth and dramatic luminescence even after many transfers.

Transportation of bioluminescent bacteria through Berea sandstone and carbonate cores was almost immediate, even without applying external pressure.

These bacteria have no hazardous effects, are simple to use and are easily detected.

\section{SIGNIFICANCE TO EOR RESEARCH PLAN}

Bioluminescent bacteria grow in geological reservoir conditions and maintain their capability to luminescence. They move freely through sandstone and carbonate formations. The data accumulated during this project establishes the laboratory parameters for using bioluminescent bacteria as geological tracers. In addition to anhanced oil recovery these natural bioluminescent tracers have great potential for application in the environmental monitoring of natural resource and fossil fuel development and clean-up.

\section{FUTURE RESEARCH PLANS}

Adaptation to higher temperature and the limitations of other parameters while maintaining visible luminescence will determine the extent to which bioluminescent tracers can be used for industrial applications - in other words, by independent oil operators.

The scale-up and field applications of bioluminescent monitoring will determine its limitations and regulation. This system could provide an excellent source of information for completing geological reservoir characterizations and for monitoring oil degradation in marine environments. 

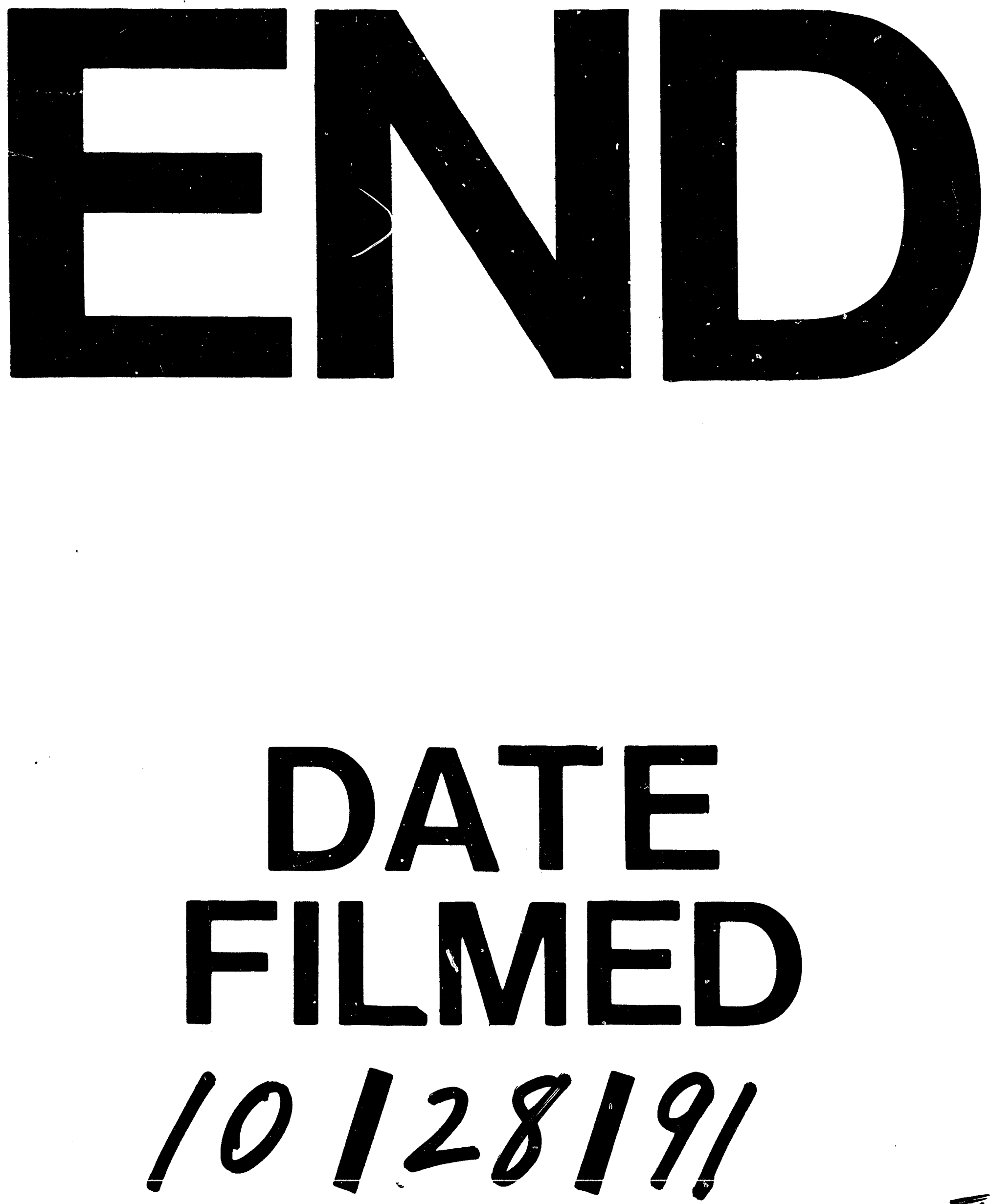

II 
